\title{
ПРАВА, УДОСТОВЕРЯЕМЫЕ СКЛАДСКИМИ ДОКУМЕНТАМИ И НЕКОТОРЫЕ АСПЕКТЫ ПРАВОВОГО РЕГУЛИРОВАНИЯ ДОГОВОРА СКЛАДСКОГО ХРАНЕНИЯ В ГРАЖДАНСКОМ ПРАВЕ РОССИЙСКОЙ ФЕДЕРАЦИИ
}

\author{
(c) 2020 Хаджимурадова Таиса Хусаиновна \\ старший преподаватель \\ Чеченский государственный университет, Россия, Грозный \\ E-mail: htaisa@mail.ru
}

В научной работе приводится научная регламентация прав, удостоверяемых складскими документами, и некоторых аспектов правового регулирования договора складского хранения в гражданском праве Российской Федерации. Раскрываются коллизионные аспекты правового регулирования договора складского хранения в гражданском законодательстве Российской Федерации.

Ключевые слова: договор складского хранения, научная регламентация, аспекты правового регулирования, термин, понятие.

Актуальность темы научной работы обусловлена широким использованием договора складского хранения и договора хранения в целом жизнедеятельности общества, и необходимостью детальной регламентации прав, удостоверяемых складскими документами и некоторых аспектов правового регулирования договора складского хранения в гражданском праве Российской Федерации.

Приведенные в настоящей научной работе выдержки из статей Гражданского кодекса Российской Федерации отображают картину различия природы договора складского хранения от общих положений договора хранения в целом.

Главной отличительной особенностью договора хранения на товарном складе от договора хранения в целом является условие возмездности отношений, возникающих и складывающихся в процессе правового регулирования.

Ученые цивилисты в своих научных трудах приводят умозаключения о том, что данное основополагающее условие характеризуют конституционность договора складского хранения [1].

В случае нарушения товарным складом условий о возмездности заключения договора складского хранения, данный договор будет регулироваться не по специализированным нормам Гражданского кодекса Российской Федерации регулирующего отношения складского хранения, а по общим нормам главы 47 Гражданского кодекса Российской Федерации.

Таким образом, будет нарушена гражданскоправовая природа договора складского хранения.
Также одним из основных отличительных черт является и то, что договор складского хранения исходя из императивности статьи 907 Гражданского кодекса Российской Федерации является реальным, в отличие от договора хранения, который в соответствии с основополагающими требованиями статьи 886 Гражданского кодекса Российской Федерации, может быть и консенсуальным.

Кроме того, еще одной не менее важной отличительной особенностью договора складского хранения является его предмет.

Так, предметом договора складского хранения является «товар», вместе с тем, Гражданский кодекс Российской Федерации не содержит легального определения данного консолидированного понятия.

Определение данного понятия обозначено в Законе Российской Советской Федеративной Социалистической Республики от 22 марта 1991 года № 948-1 «О конкуренции и ограничении монополистической деятельности на товарных рынках».

Статья 4 указанного выше Закона Российской Советской Федеративной Социалистической Республики регламентирует, что «товар - продукт деятельности (включая работы, услуги), предназначенный для продажи, обмена или иного введения в оборот» [2].

Вместе с тем, необходимо отметить, что данное определение дано в специализированном нормативном правовом акте, в этой связи, использоваться, и применятся, может лишь в определенных отношениях, в данном случае в 
области конкуренции и ограничении монополистической деятельности.

С учетом изложенного, необходимо сделать вывод, что используемый в отношении договора складского хранения термин «товар» не совсем корректен, так как он подчеркивает исключительно предпринимательские отношения, поэтому в данном случае наиболее приоритетным будет использование термина «вещь».

Использование данного термина будет способствовать воспрепятствованию возникновения юридических коллизий, а также более полному и детализированному правоприменению.

В этой связи, позиция законодателя по наделению предметом договора складского хранения «товара» некорректна.

Также, для договора складского хранения присуща в отличие от договора хранения иррегулярное хранение, то есть хранение с обезличением хранимого имущества.

Законодатель в Гражданском кодексе Российской Федерации не дает легального понимания и определения имуществу, выдаваемому поклажедателем хранителю по договору складского хранения, а лишь ограничивается нормой предусматривающей, что «поклажедателю возвращается равное или обусловленное сторонами количество вещей того же рода и качества».

В этой связи, возникают закономерные вопросы, кто является собственником имущества?

В правовой доктрине данный вопрос остается коллизионным, так, некоторые ученые считают, что собственником в данном виде хранения является хранитель, однако тогда чем же будет отличаться договор складского хранения от договора займа.

Также, одной из наиболее распространенных является и версия об общей долевой собственности нескольких поклажедателей, отдавших однородный товар хранителю на хранение.

Вместе с тем, и данная версия является спорной по тем основаниям, что возможно ли применение общих норм гражданского законодательства Российской Федерации, регулирующего вещные права к иррегулярному хранению.

Кроме того, необходимо обратить внимание на положение статьи 918 Гражданского кодекса Российской Федерации, определяющей порядок хранения вещей с правом распоряжения имущества хранителем по договору складского хранения.

Однако, в случае распоряжения имуществом поклажедателя хранителем, возникает проблемный аспект регулирования выдачи складских свидетельств, так как в случае перехода права распоряжения имуществом поклажедателя хранителю нарушается сущность складского свидетельства как товарораспределительной ценной бумаги, а также по всем признакам данный договор будет приобретать природу договора займа.

Более того, в связи с возможным пробелом в законодательстве, относительно нарушения сущности складских свидетельств с применением положений договора займа, следует обратить внимание и на то, что складские свидетельства, выступающие в гражданском обороте в качестве товарораспределительной ценной бумаги, должны иметь гражданско-правовую природу оборотного документа наравне с тем имуществом, которое было сдано на хранение хранителю по договору складского хранения. При этом, вызывает сомнение возможность наличия юридической силы такого складского свидетельства, так как непосредственно у поклажедателя нет правомочия распоряжения имуществом, сданным на хранение.

В этой связи, возникает целесообразность внесения изменений в Гражданский кодекс Российской Федерации, относительно урегулирования проблемного вопроса, обозначенного выше.

Также вызывает отдельный интерес вопрос субъектного состава по договору складского хранения. Так, по договору складского хранения одной из сторон выступает товарный склад. Статья 908 Гражданского кодекса Российской Федерации предусматривает, что «склад общего пользования в отличие от обычного товарного склада обязательно должен являться коммерческой организацией с лицензированием деятельности» [3].

Однако, Федеральный закон от 4 мая 2011 года № 99-Ф3 «О лицензировании отдельных видов деятельности» не содержит обязательного указания на лицензирование деятельности товарного склада общего пользования, а содержит требования лишь об обязательности лицензирования услуг, оказываемых обозначенным складом.

Второй стороной по договору складского хранения выступает поклажедатель, в силу прямого указания в законе товаровладелец, то есть держателем одной стороны складского свидетельства, который в обязательном порядке дол- 
жен быть владельцем товара, осуществляющий предпринимательскую деятельность. Данная прямая ссылка на правовой статус поклажедателя по мнению большинства ученых ограничивает сущностный аспект и природу договора складского хранения.

Так, если прямо толковать данную норму, вытекает, что товарный склад может принимать имущество на хранение лишь при условии того, что он является товаром, предназначенным для осуществления предпринимательской деятельности, и поклажедателем является индивидуальный предприниматель, зарегистрированный в установленном порядке в Едином государственном реестре индивидуальных предпринимателей Российской Федерации.

С учетом определенного, необходимо отметить императивность внесения соответствующих изменений в гражданское законодательство Российской Федерации в целях полного урегулирования отношений, возникающих в рамках хранения имущества на товарном складе.

В соответствии со статьей 887 Гражданского кодекса Российской Федерации договор хранения должен обладать письменной формой заключения.

Согласно статье 907 Гражданского кодекса Российской Федерации простая письменная форма договора складского хранения считается соблюденной, если его заключение и принятие товара товарным складом удостоверены выдачей складских свидетельств.

Вместе с тем, в правовой доктрине идут активные обсуждения возможности складских документов являться удостоверительным документом заключения договора складского хранения.

Основной и первостепенной коллизией в данном случае, согласно положениям статьи 915 Гражданского кодекса Российской Федерации, является возможность передачи складского свидетельства иным лицам.

Кроме того, природа удостоверения договора складского хранения складскими свидетельствами отображается не совсем корректной, так как при направлении оферты на заключение договора складского хранения и принятии акцепта, складские свидетельства должны являться второстепенными от непосредственно договора складского хранения [4].

Аргументом, свидетельствующим и отображающим доводы невозможности учета склад- ских свидетельств удостоверительным документом заключения договора складского хранения, является прямое указание пункта 3 статьи 434 Гражданского кодекса Российской Федерации в соответствии с которой «письменная форма договора считается соблюденной при условии, что стороной по договору была направлена письменная оферта, и на нее последовал акцепт» [5].

Также необходимо отметить, в связи с тем, что складские свидетельства считаются ценными бумагами, вызывает вопрос относительно возможности быть одновременно и формой договора складского хранения, так как складское свидетельство ввиду прямого указания в гражданском законодательстве Российской Федерации, является лишь удостоверительным документом, подтверждающим факт принятия имущества поклажедателя товарным складом на хранение.

Итак, на основании определенного и изложенного необходимо отметить следующие основополагающие моменты:

1. Складские свидетельства являются ценными бумагами, однако одновременно не могут являться и формой договора складского хранения;

2. Складские свидетельства являются документами, подтверждающими принятие имущества товарным складом от поклажедателя на хранения по договору складского хранения;

3. Складские свидетельства не являются правоустанавливающими документами, подтверждающими право собственности на имущество, переданное поклажедателем товарному складу на хранение по договору складского хранения;

4. Складские свидетельства наравне с удостоверительными документами, подтверждающими принятие товара товарным складом от поклажедателя на хранение по договору складского хранения, также и являются залоговыми документами, подтверждающими факт наличия обязательственных отношений стоимостного характера, выраженных в денежном эквиваленте.

С учетом изложенного, необходимо отметить, что, лишь устранив все имеющиеся пробелы и коллизии в нормах, регулирующих договор складского хранения, можно избежать недостаточной регулированности отношений в данной области. 


\section{Библиографический список}

1. Брагинский М.И., Витрянский В. В. Договорное право. Книга третья. М., 2015.- С 755.

2. Закон РСФСР от 22 марта 1991 года № 948-1 «О конкуренции и ограничении монополистической деятельности».

3. Гражданский кодекс Российской Федерации часть первая от 30 ноября 1994 г. № 51-Ф3, часть вторая от 26 января 1996 г. № 14-Ф3, часть третья от 26 ноября 2001 г. № 146-Ф3 и часть четвертая от 18 декабря 2006 г. № 230-ФЗ. ст 908.

4. Шаталов А. А. Проблемы регулирования обращения складских свидетельств // Рынок ценных бумаг. 1997. № $4-$ C.25.

5. Гражданский кодекс Российской Федерации часть первая от 30 ноября 1994 г. № 51-Ф3, часть вторая от 26 января 1996 г. № 14-Ф3, часть третья от 26 ноября 2001 г. № 146-Ф3 и часть четвертая от 18 декабря 2006 г. № 230-ФЗ. ст 434. 